\title{
FACTORS OF INFLUENCE IN CHOOSING ACCOMMODATION: A STUDY WITH REFERENCE TO MAS VILLAGE, AN ARTISTIC HERITAGE VILLAGE IN UBUD - BALI
}

\author{
P. R. Pertiwi ${ }^{1}$, A. S. Sulistyawati ${ }^{2}$ \\ ${ }^{1}$ Assistant Professor, Faculty of Tourism, Udayana University, Bali, Indonesia \\ ${ }^{2}$ Assistant Professor, Faculty of Tourism, Udayana University, Bali, Indonesia \\ ratihpertiwi@unud.ac.id
}

\begin{abstract}
This paper attempts to identify the factors that influence foreign tourists to choose accommodations in Mas Village - an artistic heritage village in Ubud, Bali. As the accommodations are in the village, tourists' motive in choosing accommodation may be different from accommodations in the big cities. The research took place in Mas Village, considering this village has been experiencing a big spike in the growth of tourists accommodation, while based on the data of 2012 until 2017 - the 87 percents of the tourists who visit this village are foreign tourists. It is known that Mas Village is one of villages in Bali fundamentally identified as an artistic countryside by focusing in artistic of wood carving since 1930s. Primary data is collected from the foreign tourists as respondents who stay in accommodations in Mas Village during June 2019, then the data is analysed using Factor analysis. The result of the factor analysis shows that location emerges as the key factor that influences tourists in choosing accommodation among three others factors. Additionally, an interesting finding from the study is how local touch and security form as one factor. By understanding the influence factors, those accommodations in Mas Village will be able to develop marketing strategies that appeal to this segment of tourists and create meaningful points of differences. However, as this research is focusing in foreign tourists, the future studies concerning how domestic tourists choose their accommodation in Mas Village is highly expected, in order to compare with foreign tourists' perspective in this research.
\end{abstract}

Keywords: Factors of Influence; Accommodation; Factor Analysis; Ubud

\section{INTRODUCTION}

Somehow accommodation is the basis of the tourism industry because it is a vital and fundamental part of providing tourism activities. During travelling, tourists are far from their home, naturally need a place, namely accommodation for a place to rest - in this case staying overnight, as their basic needs. This has led to the emergence of commercial accommodation, where each accommodation has a different level of service and facilities depending on the type of accommodation (Poudel, 2013). 
As a crucial factor of tourism product for tourists, accommodation itself has several type, size, and also characteristics that can determine the level and value of tourism in each destination. Whereas tourist accommodation usually refers to conventional hotels from several categories, then alternative accommodation itself refers to guest houses, apartments and commercial houses that provide paid accommodation for tourists in the short term. This alternative accommodation is different from conventional hotels in terms of service, facilities, that personalized by authentic local touch (Henning \& Willemse, 1999; Nuntsu, Tassiopoulos \& Haydam, 2003 in Gunasekaran \& Anandkumar, 2012).

According to Setzer and Munavist (2009) in Simarmata et al. (2017) accommodation is everything that is provided to meet someone's needs when traveling. Accommodation can be a place where a tourist can stay, rest, eat, drink, bath, and so on. National Institute of Open Schooling states that accommodation is one of the basic needs for any tourism activity. Travelers and tourists need lodging for rest, while they are on a tour. Accommodation in the form of low budget lodges/hotels to world class luxury hotels is available at all the major tourist destinations to provide the tourist a home away from home. These are establishments that provide a place for the tourist to stay i.e. lodging facilities which are paid for the duration of the stay by the tourist. There are various types of accommodation which are being used by tourists regularly. Travel agents and tour operators generally include one of the following types of accommodation in the itinerary.

Nutsugbodo (2016) also suggested that within the framework of the hospitality and tourism industry, accommodation plays a very significant role. Accommodation, thus, is an indispensable element in the development and promotion of tourism in any destination. The scope and quality of accommodation facilities available can both mirror the extent of tourism development at the destination and also persuade visitors to choose that destination. Tourist accommodation as an establishment which offers its facilities and services to individuals or groups. Examples include, but are not limited to hotels, motels, guesthouses, and company apartments/chalets. However, in its entirety, it can be defined as any facility that provides a psychological base for tourists or individuals who are temporarily away from their usual place of residence or work (O. A. Akyeampong, 2007).

As stated by Dei Mensah \& Mensah (2013) principally, bedrooms are the primary products that accommodation facilities offer to their clients. This, nevertheless, a host of other facilities and services offered for sale include restaurants and bars (food and beverage), recreational amenities (swimming pools, tennis courts, horse riding), health facilities (spas) and conference and meeting facilities among others for use by visitors. In modern times, accommodation facilities place great emphasis on conferencing and meetings as a result of the growth in business tourism.

Moreover, according to Act No. 10 of 2009 Concerning Tourism released by Ministry of Tourism and Creative Economy of Republic of Indonesia, tourism business shall mean the business providing the goods and/or services for the fulfillment of the tourists' need and tourism administration. By this, tourism business shall cover 13 categories, including accommodation provision. Regarding to this law accommodation provision business shall mean the business providing 
the inn service that can be equipped with the other tourism service. The accommodation provision business may in terms of hotel (classified hotel and nonclassified hotel), villa, cottage (including homestay), campground, caravan stopover, and other accommodation used for tourism purpose. ${ }^{1}$

However, the high level of competition in marketing in the hospitality industry, requires companies in the field to understand tourists as consumers, as well as their decision to buy a product, as a goal to benefit from the competition. By having a clear vision of the needs of tourists, business people in the hospitality sector will be able to survive and develop properly. Unfortunately, research in hotel marketing is still limited to analyzing tourist-related data, limited to sociodemographic data and geographical data of tourists obtained when tourists make reservations and when registering for check-in at a hotel. This database is still not enough to better understand tourists in making a decision to buy a product, in this case choosing accommodation that is used as a place to stay during their tour. To achieve success in the accommodation business, companies must analyze tourists' decision making in choosing accommodation more deeply (Baruca \& Civre, 2012).

According to Kotler \& Keller (2008) there are several processes that shape consumer assessment of a product consciously and rationally, first, consumers try to satisfy a need; second, consumers look for certain benefits from product solutions and; third, consumers see the product as a group of attributes with various abilities to deliver the benefits needed to satisfy needs. Additionally, there are 4 attributes to accommodation that can form consumer preferences before buying or choosing the accommodation. They are location, cleanliness, atmosphere, and price (Kotler \& Keller, 2008) as it is specified below:

a. Location

Location as a place for locating service companies that consider easy access by public transportation; a place that can be seen clearly from a normal viewing distance; traffic; a large, comfortable and safe parking area for both twowheeled and four-wheeled vehicles; a sufficiently wide space available for future business expansion; the surrounding area which is wide enough for future business expansion; the surrounding area that supports the services offered; and competition, which is the location of competitors.

Location is both a component of the hotel product and a key determinant of the availability of a hotel's operations (O. A. Akyeampong, 2007). Thus, hotel location selection has important strategic implications (Adam \& Amuquandoh, 2013). The spatial distribution of accommodation units is determined by several factors. These may vary based on the traditional functions of the city as well as the cultural, social and general economic activities of the city (Chou et al., 2007; Yang, 2004). Factors deemed to have an influence on location decisions of accommodation facilities include the size of the city, Tourism Development In Ghana's BAR: Demand And Supply Dynamics functions of the city, transportation systems, social habits and patterns and the economic/business climate (O. A. Akyeampong, 2007).

b. Cleanliness

\footnotetext{
${ }^{1}$ Act No. 10 of 2009 concerning Tourism released by Ministry of Tourism and Creative Economy of Republic of Indonesia, Article 1 Point 7; Article 14 item f.
} 
Cleanliness of the hotel is very important because if cleanliness is always maintained, it will make tourists feel at home and feel comfortable. Cleanliness as one of the concerns that is very much considered by tourists, because if the environment around the hotel area is dirty, it indirectly makes tourists not interested in choosing accommodation and becomes a minus value for the accommodation.

c. Atmosphere

The hotel atmosphere gives an attractive impression for tourists who want to stay in an accommodation. most tourists look for an atmosphere that has not been found in the place before. As cited by Heide \& GrØnhaug (2006) from the studies by Troye \& Heide (1987) Atmosphere is distinguished by guest surveys in Norway as a basic variable for clarifying fulfillment among hotel guests, regardless of which a part of the country the hotel was located, variety of hotel, or nationality of the guests. In the rising field of culinary arts and meal science, the atmosphere within the restaurant is mostly emphasized as a key factor for ensuring a successful meal experience (Hansen et al., 2005; Kokko, 2005; Gustafsson et al., 2006 in Heide \& GrØnhaug, 2006).

d. Price

Price is the most easily adjusted marketing mix element, product features, distribution channels and even promotion require more time. Prices can communicate the company's intended value position to the market regarding its products and brands. Price has two main benefits, namely obtaining the highest benefit or utility based on purchasing power, and price can educate consumers about product factors, such as quality. Bojanic (1996) defined that it is essential for hotel to use price, room rate, as a way to maximize genuine income relative to potential revenue. He also added that there are some studies within the hospitality literature that observe price as a strategic variable and its use in positioning hotels (Lewis 1990; Shaw, 1992 in Bojanic, 1996). Shaw (1992) in Bojanic (1996) concludes that consumers' price perceptions are important in developing a price range for positioning, and tactical price decisions can then be made within this range so as to not negatively affect brand image.

The growth of accommodation in Bali spreads in its 9 regencies, spesifically Regency of Jembrana; Regency of Tabanan; Regency of Badung; Regency of Gianyar; Regency of Klungkung; Regency of Bangli; Regency of Karangasem; Regency of Buleleng; and Municipality of Denpasar. Gianyar regency where this study is conducted, located in the Center of Bali Province in Indonesia, known as the center of art, craft, and culture in Bali. On the word of Vickers (2019) in Bali, heritage is almost identical with tradition. The popular perspective relating to Bali's heritage generally will refer to the village and wider district of Ubud. For tourist coming to Bali, Ubud is interchangeable with traditional Balinese culture, while spritual tourism and digital networking have been tinting this destination since the last decade. As we search for the keyword "Ubud, Bali, tradition" in the search engine, it will link to promotional websites, travel articles and advertisements that refer Ubud as a destination to witness the Balinese tradition. Both for tourists and insiders in Ubud, the image of this tradition is synonymous with the idea of regional heritage. According to him Gianyar had a series of living arts practices at the beginning of the twentieth century. 
One of tourist destination in Gianyar, that known worldwide as an international tourists village is Ubud. As an "international village", Ubud wins many title and awards, namely Best City in Asia in 2010 by Conde Nast Traveler and also Most Favorite Destinations in Asia (Asia's Top 10 Destinations) by TripAdvisor in 2014 (Narottama, 2016). It is also noted that in the 1930s there were increasingly more foreign tourist visits to Ubud, Bali (Staab, 1997 in Ardhana, 2018). As seen in the Table 1 below, the foreign tourist visits in Ubud is higher compared with domestic tourist.

Table 1. Number of Domestic and Foreign Tourist Visit in Ubud Sub-District in 2012 - 2017

\begin{tabular}{ccccc}
\hline \multirow{2}{*}{ Year } & Number of Tourist (Person) & $\begin{array}{c}\text { Total of } \\
\text { Number of } \\
\text { Tourist } \\
\text { (Person) }\end{array}$ & $\begin{array}{c}\text { Persentag } \\
\text { e (\%) }\end{array}$ \\
\cline { 2 - 3 } & Domestic & International & 191,025 & - \\
\hline 2012 & 37,531 & 153,494 & 192,215 & 0,62 \\
\hline 2013 & 33,885 & 158,330 & 213,912 & 10,14 \\
\hline 2014 & 42,809 & 171,103 & 199,532 & $(7,21)$ \\
\hline 2015 & 33,769 & 165,763 & 873,103 & 33,75 \\
\hline 2017 & 32,545 & 840,558 & $1,523,983$ & 42,70 \\
\hline & 26,796 & $1,497,187$ & $\mathbf{3 , 1 9 3 , 7 7 0}$ & $\mathbf{9 4 , 4 2}$ \\
\hline Total & & $\mathbf{5 3 2 , 2 9 5}$ & $\mathbf{1 8 , 8 8}$ \\
\hline
\end{tabular}

Source: Tourism Office of Gianyar Regency, Indonesia, 2018

As presented by Tabel 1 the average growth of domestic tourist and foreign tourists arrivals in Ubud Sub-District is 18.88 percent. In addition, it can also be seen the level of foreign tourist visits in the Ubud Sub-District is greater compared to domestic tourists. Considering the rapid level of foreign tourist visits in this destination, certainly sufficient amount of accommodations are needed in order to equip one of their basic needs, viz., a place to stay during their vacation. Table 2 shows that Ubud Sub-District has the highest number of hotels among others, specifically 17 star hotels and 863 non star hotels. 
Table 2. Number of Star Hotels and Non-Star Hotels in

Each Sub-District in Gianyar Regency in 2012 - 2017

\begin{tabular}{lcc}
\hline \multicolumn{1}{c}{ Sub-District } & Classified Hotel & Non Classified \\
\hline Sukawati & 1 & 76 \\
\hline Blahbatuh & 2 & 92 \\
\hline Gianyar & - & 11 \\
\hline Tampaksiring & - & 84 \\
\hline Ubud & $\mathbf{1 7}$ & $\mathbf{8 6 3}$ \\
\hline Tegalalang & - & 90 \\
\hline Payangan & 5 & 56 \\
\hline TOTAL & $\mathbf{2 5}$ & $\mathbf{1 2 7 2}$ \\
\hline
\end{tabular}

Source: Bureau of Statistics of Gianyar Regency, Indonesia, 2018

Mas Village is a village in Ubud Sub-District among 7 others villages, namely, Kedewatan Village, Lodtunduh Village, Peliatan Village, Petulu Village, Sayan Village, Singakerta Village, and Ubud Village. Mas Village is famed as an Artistic Heritage Village, its reputation of its extraordinary wood sculptures known for centuries. Vickers (2019) also mentioned that the carving village of Mas is referred to as neighbouring artistic centres in Ubud, besides the music centre of Peliatan. Since the 1930s until the 1990s, Mas Village witnessed continuous evolution and creative experimentation in its woodcarvings. Local painters and woodcarvers - which previously carved masks to used as instruments in their local ceremonies and festivals - began to absord and adapt new materials and techniques of painting and sculpting that brought by European artists who settled in Ubud in the period of the 1930s. These new techniques successfully captured the attention of both domestic and international guests who came to Bali, thus, those local artists were able to make comfortable livings. In the 1980s until 1990s Mas Village remained a major destination for tourists, as they captivated by its remarkable yet reasonably prices of its sculptures and masks (Jenkins \& Romanos, 2014)

The Government of Gianyar Regency through The Decree of the Regent of Gianyar No. 429/E-02/HK/2017 concerning the establishment of a Tourism Village (Desa Wisata) in the Regency of Gianyar has designated Mas Village as a Tourism Village (Desa Wisata). This village becomes one of the most favorite destinations in Ubud since it has two tourism village such Nyuh Kuning and Tarukan. It is seen by the development of varied accommodation options in this village. As shown in Tabel 3 below, there are 82 accommodations in this villages such as 10 non-stars hotels, 30 bungalows, 40 homestays, and 2 hotels.

Seeing the development of tourism activities in Mas Village, particularly the level of foreign tourist visits in Ubud which is higher contrary to domestic tourist visit and also the growth of accommodation, and also it is seen that this village has quite a large and varied number of accommodations, naturally, it is considerably could lead to a kind of tight competition among those accommodation. On the other hand, those accommodations should be able to analyze the factors that influence tourists' decision in choosing accommodation during their vacation. 
Thus, this paper attempts to determine the factors that influence foreign tourists decision-making in choosing accommodations. By understanding the influence factors, those accommodations in Mas Village will be in a position to develop marketing strategies that appeal to this segment of tourists and create meaningful points of differences.

Table 3. Number of Accommodation in Mas Village, Ubud in 2018

\begin{tabular}{clc}
\hline No. & Type of Accommodation & Number of Accommodation \\
\hline 1 & Non-star hotel & 10 \\
\hline 2 & Bungalow & 30 \\
\hline 3 & Homestay & 40 \\
\hline 4 & Hotel & 2 \\
\hline & TOTAL & $\mathbf{8 2}$ \\
\hline
\end{tabular}

Source: Purwaningsih et al, 2018.

\section{METHODOLOGY}

This study uses a quantitative descriptive approach consisting of descriptive statistics and statistical inference to determine the factors that influence foreign tourists in choosing accommodations in Mas Village, Ubud. Sources of data in this study were obtained by distributing questionnaires to 50 respondents (foreign tourists) who stay at accommodations all the four categories namely non-classified hotels, bungalows, homestays, and hotels in Mas Village during June 2019. The sampling technique used in this study was quota sampling.

The research instrument - a questionnaire with 15 questions - was developed with reference to decision making aspects in choosing accommodation from Kotler \& Keller (2008). The questionnaire provided information about foreign tourists preferences in choosing accommodation regarding several criteria, namely, location; cleanliness; atmosphere; and price. The first part of the questionnaire with closed questions concerned demographic characteristics and travel behaviour. Demographic characteristics determined country of origin, gender, age range, marital status, level of education and occupation of respondents. Travel behaviour questions showed length of stay, purpose of visit, source of information of the respondents, and type of accommodation that respondents chose. The second part of questionnaire with the Likert scale was related to consumer preferences in choosing the accommodation questions and concerned the level of importance of each indicated factor affecting decision-making. 15 Likert scale questions about consumer preferences in choosing the accommodation were divided into 4 categories, specifically, location; cleanliness; atmosphere; and price, which directly relate to decision-making in choosing accommodation. Data received from the survey was processed by using the IBM SPSS 21.0.

Before distributing questionnaires to 50 respondents, validity and reliability tests were carried out on 30 questionnaires that were used as research instruments. The results obtained indicate that the instrument used was declared valid and reliable. After being declared valid and reliable, the distribution of questionnaires to 20 respondents with the same instrument continued. Validity test is performed 
on each instrument to determine the level of validity of the instrument. The results of the validity testing output in this study used the reliability analysis technique in IBM SPSS 21.0. As the results of the validity test of the 15 items have values above 0.30 , it can be concluded that all instruments on the 15 items are valid. In addition, these 15 items were declared reliable as the Cronbach alpha value was above 0.6.

Factor analysis (using principal component analysis) was used to identify the factors in influence in choosing accommodation. Data collected from a sample of 50 respondents who had rated their agreement/disagreement with the 15 stated variables in the questionnaire was subject to Factor analysis. The 15 items were factor analyzed using Principal Component analysis after ascertaining the appropriateness of Factor analysis (Malhotra \& Dash, 2005)using the 5 level. Furthermore, the Kaiser-Meyer-Olkin Measure of Sampling Adequacy (KMO or MSA) and Bartlett's Test of Sphericity are used to measure the suitability of the sample. Samples are considered feasible if the correlation value between variables meets the specified requirements (MSA $\geq 0.5$ ). While the significance value measured through Bartlett's Test of Sphericity shows that the 15 items have a significance value (sig) $<0.05$ so that each item can be further analyzed.

Factors with eigenvalue greater than 1 and a loading of 0.5 and above were then rotated using varimax rotation with Kaiser normalization. In order to summarize the information contained in the original variables, a smaller number of factors should be extracted. In this research, approaches based on eigenvalues and Scree plot are used to determine the number of factors. Based on the eigenvalue criterion (that is, eigenvalue $>1$ ), four factors emerged. To confirm the number of factors, a scree plot was drawn.

\section{Demographic Profile of Respondents of the Study}

The demographic profile of the respondents of the study describes the various relevant characteristics the researcher collected for the purpose of the study. The main characteristics use to describe the respondent are categorised as; country of origin, gender, age range, marital status, level of education, occupation, length of stay, purpose of visit, source of information, and type of accommodation to stay. These categories are detail described in the Table 4 below.

Table 4. Demographic Profile of Respondents

\begin{tabular}{lcc}
\hline Country of Origin & Frequenc & Percentage (\%) \\
Australia & $\mathbf{y}$ & 18 \\
Austria & 9 & 4 \\
Denmark & 2 & 6 \\
U.K & 3 & 6 \\
Italy & 3 & 4 \\
Germany & 2 & 2 \\
Poland & 1 & 4 \\
Portugal & 2 & 2 \\
France & 1 & 6 \\
Scotland & 3 & 2 \\
Spain & 1 & 6
\end{tabular}


Gender

Female

Male

Age Range

$>20$

6

$21-25$

4

$26-30$

38

$31-35$

22

$36-40$

10

$41-45$

$46-50$

4

$<51$

Marital Status

Single

Married

Level of Education

High School

Diploma

24

Bachelor

Master

44

$\mathrm{PhD}$

4

Abstain

Occupation

Enterpreneur

24

Private Employees

12

14

Civil Servant

48

Others (Researcher)

Retired

2

Abstain

1

4

8

\section{Length of Stay}

2 nights

3 nights

$4 \quad 8$

4 nights

5 nights

23

46

6 nights

10

1 week

5

3

10 nights 
12 nights

2 week

10 months

\section{Purpose of Visit}

Holiday

\section{Source of Information}

Online Review
Social Media
Website
Travel Agent (Online)
Travel Agent (Offline)
Travel Magazine
Relation

Accommodation to

\section{Stay}

\section{Homestay}

Guesthouse

Villa

Hotel

$\begin{array}{cc}11 & 22 \\ 16 & 32 \\ 4 & 8 \\ 11 & 22 \\ 2 & 4 \\ 0 & 0 \\ 6 & 12\end{array}$

The table indicates that European tourists dominate Mas village by 42 percent, specifically German tourists, Portuguese and Scottish, each as much as 2 percent. Followed by tourists from Austria, Italy, and Poland each as much as 4 percent, then tourists from Britain, Denmark, France, and Spain as much as 6 percent. Followed by the number of US tourists who nearly matched the number of European tourists, which was 40 percent, and the remaining 18 percent came from Australia.

The distribution according to the gender of respondents showed that 56 percent are females and 44 percent are males. Most of respondents ( 38 percent) are 26-30 years old, 22 percent are 31-35 years old, 12 percent of respondents are 51 years old and above, further 10 percent are $36-40$ years old, and 6 percent of the respondents are below 20 years old. The rest are in the age group between 21-25 years old, ages 41 - 45 years old, and ages 46 - 50 years old, respectively are 4 percent. The results of 50 respondents' marital status indicated that 58 percent of them were single, 48 percent were married.

Table 4 further shows respondents' level of education. It can be seen that the majority of respondents ( 44 percent) hold master degree, followed by 24 percent who hold diploma degree, 18 percent of them hold bachelor degree, 8 percent of the respondents hold high school diploma, 4 percent of the respondents took doctoral degree. The remaining 2 percent of the respondents do not include their information regarding their education level.

According to Adomaitiene \& Seyidov (2017) occupation is a part of cultural, social and personal factors, which directly affect the choice, and behavior of a consumer. As the survey results showed, 48 percent of the respondents working 
as civil servant, followed by entrepreneurs by 24 percent, then respondents who are working in private companies by 14 percent, where there are 4 percent of the respondents working as researchers, 2 percent are retired, and 8 percent of the respondents does not provide information regarding their occupation.

By analyzing the length of stay of the respondents in Mas Village it is determined that the majority of foreign tourists ( 46 percent) stayed for 4 nights, 10 percent of foreign tourists stayed for 5 nights, 8 percent of them stayed for 2 nights, there are also 8 percent of foreign tourists who stayed for 10 nights. Furthermore, as many as 6 percent of tourists decided to stay for 6 nights, the same result was also seen in the group of foreign tourists who decided to stay for 3 nights. The remaining 4 percent chose to stay for 12 nights. Whereas the number of foreign tourists who chose to stay for a week is 6 percent, and 4 percent of them stayed for 2 weeks. 2 percent of foreign tourist has the longest period of stay in Mas Village (for 10 months. Regarding the purpose of visit in Mas Village, 100 percent of the respondents have the same purpose of visit, it is for a vacation.

Internet, especially social media, official online review, online booking, and website are famous sources for information among respondents with 32 percent, 22 percent, also 22 percent, and 8 percent accordingly. Only 4 percent of the respondents use conventional travel agents to find information about accommodations in Mas Village, Ubud. Furthermore, there are 12 percent of respondents get information through relationships, and none of the respondents claimed that print media both newspapers, magazines, and brochures are their source of information.

The respondents' most preferred type of accommodation is a hotel with 60 percent and the least one is a guesthouse with 4 percent. A villa is the second most chosen accommodation type ( 26 percent) followed by homestays (10 percent).

\section{RESULT AND DISCUSSION}

Finally, four factors were retained explaining 78 per cent of the total variance, those factors are considered capable of influencing tourists in choosing accommodation in Mas Village, Ubud. The summary result of the factor analysis of all the elements and sub-elements is presented in Table-2. The factor analysis yielded four dimensions that were labeled as: location, cleanliness $\&$ atmosphere, good value and local touch \& security.

Table 2. Final Factors, Items, Loadings, Communalities, and Eigen Values

\begin{tabular}{|c|c|c|c|c|c|}
\hline Factors & $\begin{array}{l}\text { Significant } \\
\text { Variables }\end{array}$ & $\begin{array}{c}\text { Factor } \\
\text { Loadin } \\
\text { gs }\end{array}$ & $\begin{array}{l}\text { Commun } \\
\text { alities }\end{array}$ & $\begin{array}{l}\text { Eigen } \\
\text { Values }\end{array}$ & $\begin{array}{c}\% \text { of } \\
\text { Varian } \\
\text { ce }\end{array}$ \\
\hline $\begin{array}{l}\text { F1: Location } \\
(\mathrm{N}=4)\end{array}$ & $\begin{array}{l}\text { Location } \\
\text { accessible }\end{array}$ & 0.899 & 0.873 & 5.748 & 38.322 \\
\hline
\end{tabular}


2 Location is

$\mathbf{0 . 9 2 2} 0.871$

) close to public facilities e.g. police station, fire department, health center, tourist information, and money changer

3 Location is near

$0.877 \quad 0.820$

) by touristic \& cultural sites

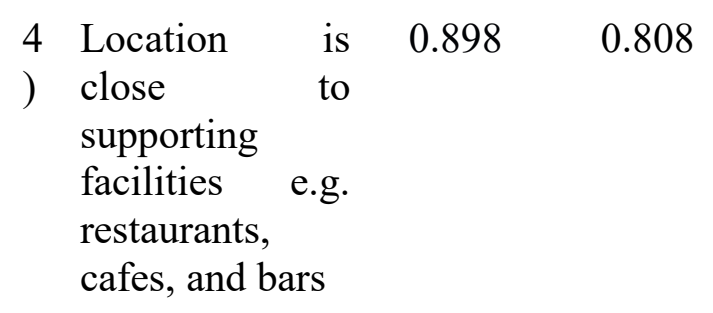

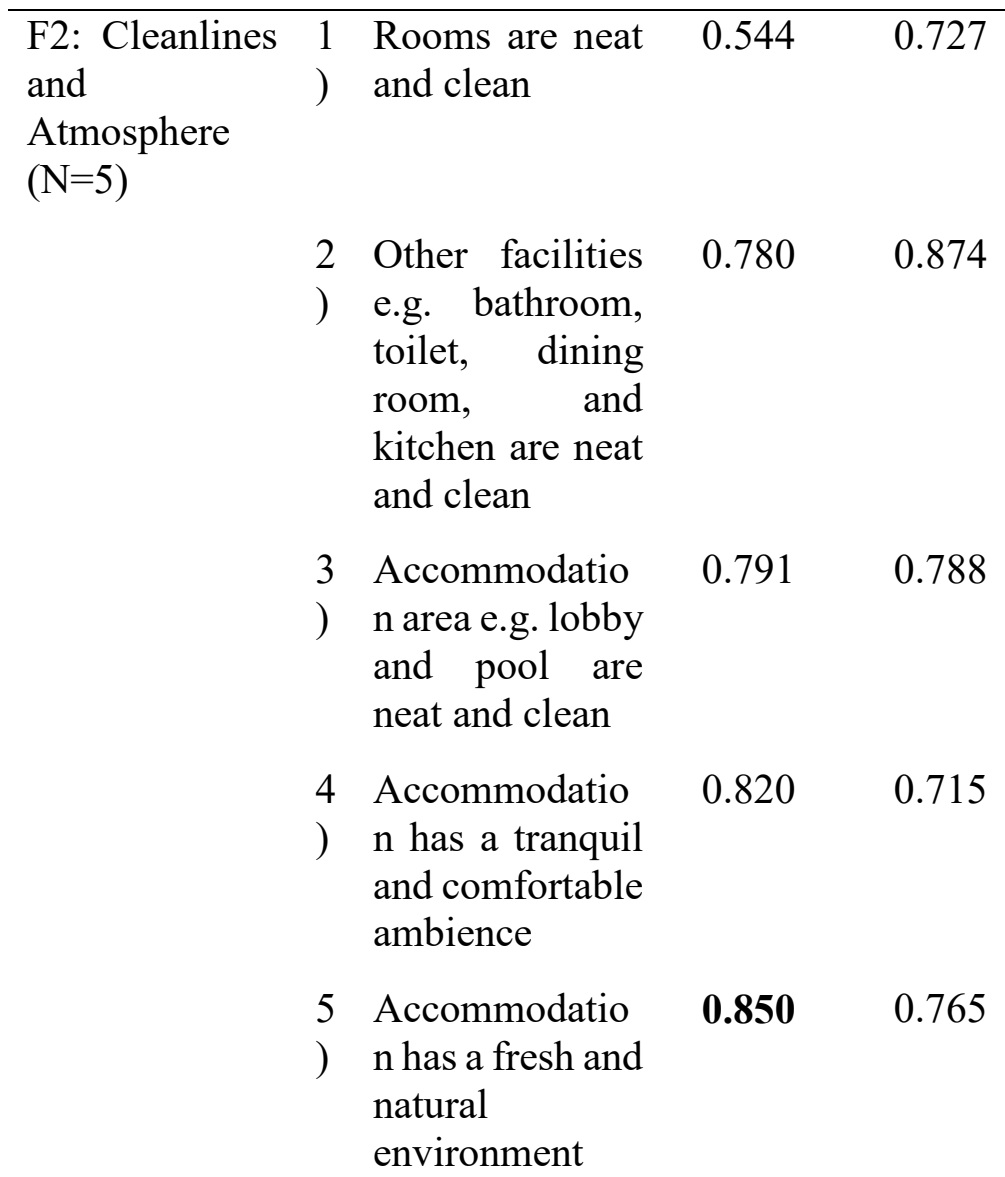

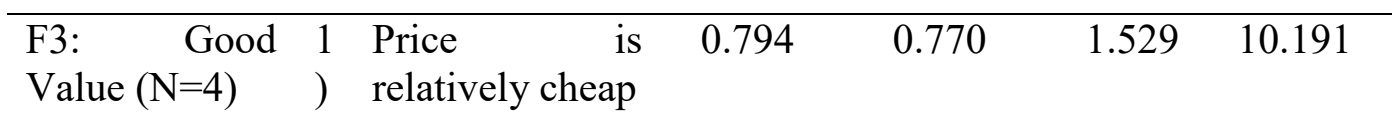




$2 \begin{aligned} & \text { Price is } \\ & \text { compatible with } \\ & \text { service they } \\ & \text { offered }\end{aligned}$
$\begin{aligned} & \text { Price is } \\ & \text { compatible with } \\ & \text { facilities } \\ & \text { offered }\end{aligned}$
$\begin{aligned} & \text { The } \\ & \text { accommodation } \\ & \text { offers } \\ & \text { interesting } \\ & \text { promotion }\end{aligned}$

\begin{tabular}{|c|c|c|c|c|c|c|c|}
\hline \multirow[t]{2}{*}{$\begin{array}{l}\text { F4: } \\
\text { Touch } \\
\text { Security } \\
(\mathrm{N}=2)\end{array}$} & $\begin{array}{r}\text { Local } \\
\text { and }\end{array}$ & $\begin{array}{l}1 \\
\text { ) }\end{array}$ & $\begin{array}{l}\text { Accommodatio } \\
\mathrm{n} \text { still implies } \\
\text { Balinese local } \\
\text { cultures }\end{array}$ & 0.776 & 0.687 & 1.075 & 7.169 \\
\hline & & $\begin{array}{l}2 \\
\text { ) }\end{array}$ & $\begin{array}{l}\text { Accommodatio } \\
\mathrm{n} \text { security is } \\
\text { safely } \\
\text { maintained (in } \\
\text { related to } \\
\text { guest's } \\
\text { belongings; } \\
\text { unpleasant act } \\
\text { by local } \\
\text { community; } \\
\text { guest privacy; } \\
\text { any other threat) }\end{array}$ & 0.682 & 0.603 & & \\
\hline
\end{tabular}

The location factor is the first factor identified through factor analysis and this factor includes four items, namely location is accessible; location is close to public facilities e.g. police station, fire department, health center, tourist information, and money changer; location is near by touristic \& cultural sites; location is close to supporting facilities e.g. restaurants, cafes, and bars. This factor accounts for 38.32 per cent variance. It highlights the importance of location and accessibility of the accommodation.

The cleanliness and atmosphere factor includes items such as rooms are neat and clean; Other facilities e.g. bathroom, toilet, dining room, kitchen are neat and clean; Accommodation Area e.g. lobby and pool is neat and clean; Accommodation has a tranquil and comfortable ambience and; Accommodation has a fresh and natural environment. This factor accounts for 22.48 per cent variance. It stresses that cleanliness, tranquil, natural and fresh environment are still much considered by the tourist while they choose their accommodation. 
The good value factor includes items such as price is relatively cheap; price is compatible with service they offered; price is compatible with facilities offered and; the accommodation offers interesting promotion. This factors accounts for 10.91 per cent variance. It indicates that the proprietors of the accommodation need to concern about the service and facilities in their accommodation that they offered to the tourist according too the price of their accommodations. Furthermore, promotion of accommodation package is still an interesting offers for tourists who are looking for the accommodation to stay.

The local touch and security factor includes items such as accommodation still implies Balinese local cultures and accommodation security is safely maintained (in related to guest's belongings; unpleasant act by local community; guest privacy; any other threat). This factor accounts for 7.16 per cent variance. It highlights the importance of maintaining a local touch through local experiences, while the tourists are still expecting their privacy are respected by the local community, and also the security in their accommodation as well as their neighborhood.

The result of the factor analysis shows that location emerges as the key factor that influences tourists in choosing accommodation. This result supports two previous studies (Baruca \& Civre, 2012; Suwantada, 2016), which reveal that the most important decision-making factor in choosing hotel or tourists accommodation is Location. There are also two others previous studies (Chu \& Choi, 2000; Luekveerawattana, 2018) that bring out location as one of the factors in choosing accommodation.

Furthermore, this research also figures that accommodation cleanliness and atmosphere cannot be separated, it makes a sense as this factor is relevant with the result study of Suwantada (2016) which defines that physical factor that covers location; atmosphere; cleanliness; size of room; and room type is the most important factor that affecting tourists in choosing accommodation.

In addition, good value explains that tourists are not only concern about the pricing term, but in the matter of how the price is compatible with the service and facilities they will get from the accommodation. It supports previous research of Gunasekaran \& Anandkumar (2012), which provide the four factors that influence tourists to choose alternative accommodation such as Guesthouses, Service apartments and Commercial homes (including Homestay and Bed \& Breakfast), namely homely atmosphere; value for money; local touch and guest-host relationship.

Moreover, while, other studies divide local touch and security into specific factors Gunasekaran \& Anandkumar (2012) they set security to the homely atmosphere factor, while local touch is set as one of the three factors. In addition, Chu \& Choi (2000) set attributes of hotel selection factors such as cleanliness; location; room rate; security service quality; and the reputation of the hotel, it is also revealed by Luekveerawattana (2018) that security system; location; and facilities are the factors in choosing accommodation. In this study, which distinguishes from other studies, is local touch and security factor that attached to one another. As this study took place not in a big city, but in Mas Village - one of the famous villages located in Ubud - Bali, as being one of the main arts and crafts village on the island, a local touch in the accommodation is remarkably expected by tourists, while at the same time they wish to have a privacy, to be respected by 
local community, and feel quite safe related to their belongings and also from any other unpleasant threats.

An interesting finding from the study is how local touch and security form as one factor. This is a new finding on the topic and can be a beneficial contribution to the scientific literature. It explains that even though tourists choose the accommodations, which are located in artistic village, and implies local culture, but they still concern regarding their security and their privacy matters. In regard to providing tourist accommodation, The Government of Gianyar Regency, management of village tourism (desa wisata) in Mas Village and also management of the accommodations in this village, can use this information as a basis references in planning for the purpose of responding to tourists' preferences.

\section{CONCLUSION}

Principally, regarding to study result the first four things that tourists consider for choosing accommodation are location; cleanliness \& atmosphere; good value; and the last but not least is local touch \& security. However, as this research is focusing in foreign tourists, the future studies concerning how domestic tourists choose their accommodation in Mas Village is highly expected, as a means to compare with foreign tourists' perspective in this study.

\section{ACKNOWLEDGMENT}

We would like to express our appreciation and our sincere gratitude to the Rector of Udayana University, The Chairman of LPPM Udayana University, and The Dean of the Faculty of Tourism Udayana University who has financially supported this research and provided the opportunity for the team to conducted this research. This paper and the research behind it would not have been possible without the above mention-funding source.

\section{REFERENCES}

Adam, I., \& Amuquandoh, F. E. (2013). Dimensions of hotel location in the Kumasi Metropolis, Ghana. Tourism Management Perspectives, 8, 1-8.

Adomaitienè, R., \& Seyidov, J. (2017). Factors Influencing Local Tourists' Decision-making on Choosing a Destination: a Case of Azerbaijan. Ekonomika, 95, 112. https://doi.org/10.15388/Ekon.2016.3.10332

Akyeampong, O. A. (2007). Tourism in Ghana: The accommodation sub-sector. Janel Publications.

Ardhana, I. K. (2018). Western Influences in The Bali Tourism Industry. 161-170.

Baruca, P. Z., \& Civre, Z. (2012). How do guests choose a hotel. Academica Turistica, 5(1), 75-84.

Bojanic, D. C. (1996). Consumer perceptions of price, value and satisfaction in the hotel industry: An exploratory study. Journal of Hospitality \& Leisure Marketing, 4(1), 5-22.

Chou, T.-Y., Hsu, C.-L., \& Chen, M.-C. (2007). A fuzzy multi-criteria decision model for international tourist hotels location selection. International Journal of Hospitality Management, 27(2), 293-301. 
Chu, R. K. S., \& Choi, T. (2000). An importance-performance analysis of hotel selection factors in the Hong Kong hotel industry: a comparison of business and leisure travellers. Tourism Management, 21(4), 363-377.

Decree of the Regent of Gianyar No. 429/E-02/HK/2017 concerning the establishment of a Tourism Village (Desa Wisata) in the Regency of Gianyar, (2017).

Dei Mensah, R., \& Mensah, I. (2013). Management of tourism and hospitality services (2nd ed.). Edsam Press.

Gunasekaran, N., \& Anandkumar, V. (2012). Factors of influence in choosing alternative accommodation: A study with reference to Pondicherry, a coastal heritage town. Procedia-Social and Behavioral Sciences, 62, 1127-1132.

Heide, M., \& GrØnhaug, K. (2006). Atmosphere: Conceptual issues and implications for hospitality management. Scandinavian Journal of Hospitality and Tourism, 6(4), 271-286.

Jenkins, L. D., \& Romanos, M. (2014). The art of tourism-driven development: economic and artistic well-being of artists in three Balinese communities. Journal of Tourism and Cultural Change, 12(4), 293-306.

Kotler, P., \& Keller, K. L. (2008). Manajemen Pemasaran (13th ed., Vol. 1). Macana Jaya Cemerlang.

Luekveerawattana, R. (2018). Key factors affecting of tourists' decisions to stay at environmental friendly hotels. Polish Journal of Management Studies, 17.

Malhotra, N. K., \& Dash, S. (2005). Marketing research: An applied orientation. Pearson/Prentice Hall.

Narottama, N. (2016). International Diaspora and Tourism : Recent Development of European Diaspora in Ubud. International Tourism Conference: Promoying Cultural and Heritage Tourism.

Nutsugbodo, R. Y. (2016). Tourist Accommodation. In O. Akyeampong (Ed.), Tourism development in Ghana's Brong-Ahafo Region: Demand and supply dynamics (pp. 73-88). Xtrym Consortium.

Poudel, S. (2013). The influence of the accommodation sector on tourism development and its sustainability: Case Study: Strand Camping, Larsmo. Centria ammattikorkeakoulu (Keski-Pohjanmaan ammattikorkeakoulu).

Act No. 10 of 2009 Concerning Tourism, (2009).

Simarmata, J., Yuliantini, Y., \& Keke, Y. (2017). The Influence of Travel Agent, Infrastructure and Accommodation on Tourist Satisfaction. International Conference on Tourism, Gastronomy, and Tourist Destination (ICTGTD 2016). https://doi.org/https://doi.org/10.2991/ictgtd-16.2017.55

Suwantada, K. (2016). Factors Affecting to Tourists in Choosing Accommodation in Buriram Province. RMUTL Journal of Business Administration and Liberal Arts, 4(2), 1-9.

Tourism Office of Gianyar Regency, Indonesia, 2018. (n.d.).

Vickers, A. (2019). Creating heritage in Ubud, Bali. Wacana, 20(2), 250-265. https://doi.org/https://doi.org/10.17510/wacana.v20i2.747

Yang, C. H. (2004). Identifying and Testing the Decision Making Factors Related to 'Key Industries' Choice of Location. Griffith University. 